\title{
Bankim's Use of Familiar Patriarchal Tropes/Frameworks in Rajmohan's Wife to Define and Re-Define Womanhood
}

\author{
Debabrata Adhikary \\ Assistant Professor, Department of English \\ Hooghly Women's College \\ Pipulpati, Hooghly, West Bengal, India \\ deboadhikary@gmail.com \\ adhikary.debabrata@yahoo.com
}

\section{Abstract}

The present paper aims to look at the concept of womanhood as defined and revised upon by Bankimchandra Chattopadhyay, in his debut novel, and, incidentally, the first Indian novel, written in English language, known as Rajmohan's Wife. Bankimchandra Chattopadhyay is the great Indian novelist, and, poet, who has given a new dimension to the genre of Bengali novel. In this present novel, he has tried to show the Bengali woman trying to come out of the conservative, conventional patriarchal ethos, and, slowly trying to make a room/space of her own. And, this, by not abandoning/rejecting patriarchy outrightly, but by staying very much within the patriarchal zone, and, yet asserting her individuality/personality.

Keywords: Womanhood, Patriarchy, Space, Individuality.

Introduction:

The objective of the present paper is to showcase/find out what exactly is womanhood, and how has Bankim tried to portray/define womanhood in the $19^{\text {th }}$ century Bengali society, and tried to improve/modify /restructure upon it, through the spirited 
character of Matangini, in the novel, Rajmohan's wife. Matangini, the central character of the novel, is not shown to have/possess an independent status/identity; rather she is shown as carrying/bearing someone else's name and identity; is seen as Rajmohan's Wife and not as Matangini, which is evident from the title itself. And the very fact of naming the novel as Rajmohan's Wife, shows how Bankim conforms to the stereotypical patriarchal vogue/trope, prevalent in literature and society at that point of time. And throughout the novel, we see Matangini and her journey of life, essentially revolving around the patriarchal framework, and negotiating with its various/numerous impositions, demands, and exploitations till the very end. Starting from her father (who thinks of no ill, when marrying his elder daughter to a much elder person, Rajmohan), to her husband (the cruel, brutal, imperious, and scheming Rajmohan); to the love of her life, and her brother-in-law (the western educated Madhav); and ultimately the ultimate villain of the novel Mathur - all try to codify or view her as an essentially woman, who is an exclusive male property, and whose only happiness lies/can lie in marrying (by a successful transfer/handing over of the custody/proprietorship from one male to another); or is someone, who can be thought of being easily possessed by a male anytime without even bothering/caring for her consent, (like Mathur, only because he is a male) or is seen as someone, whose attachment with a male can defame his dignity/honour/fame, however, beneficial she might prove to him in saving his property and perhaps life (like Madhav, who constantly tries to drive Matangini away from her presence, instead of consoling and helping her out in her time of utter crisis). Of Matangini's father we get to know very little. Probably, we find him twice in the text in the fourth chapter, titled as The History of the Rise and Progress of a Zemindar Family, we get introduced to him as a poor Kayastha, whose only possession is his two daughters who 'had not their equal in beauty or in dutiful and amiable conduct'; and, then, at the penultimate end, when, after Rajmohan's transportation by law, and, Matangini's realization of her inability to live in the same house 
of Madhav, he re-appears and takes her daughter back home, after getting an intimation from Madhav. He is not even named in the novel, which shows his relative insignificance as compared to other characters, especially male characters. But he seems to be the very first person in Matangini's life who gives her the impression that a girl is not only a property but also a burden for a father, and the best thing he can do is to dispose her of by marrying her to a well-off person, however, huge the age difference might be:

Yet, when the marriage took place, Matangini's father thought he had not chosen ill. Rajmohan had indeed then reached manhood and was therefore unsuited in age-but this was not minded much......He lived in an adjoining village and the prospect that no great distance would separate father and daughter served greatly to favour the match in the eyes of the former...... The circumstance which promised to rescue Matangini form the pinchings of poverty seemed to her father to be another and the greatest recommendation, and the marriage accordingly took place. (17-18)

It seems a wonder that a spirited woman like Matangini cannot express her wish to marry Madhav (to whom, as we get to know later on, she has a liking, from her younger days and it has been mutual also) and not Rajmohan, to her father, and, wilts, as it were, under her father's wish, which seems to be the last word for her. So, we see that she has to conform to the typical patriarchal societal structure, which expects a woman to be obedient, submissive, and, not at all possessing a retorting nature. From father, to husband, Matangini, however, continues her same humble disposition/demeanour. When the novel opens, we find her as an obedient wife, who religiously follows her husband's instructions to stay indoor throughout the day and denies the invitation of Kanakmayee to go out to fetch water from outside: 
At this the younger woman became grave and said, 'You know, Kanak Didi, I never fetch water.'

'That is why I am asking you to,' replied Kanak. 'Why should you remain in a cage all the day. Do not all other housewives draw water?'

The young woman said firmly, 'I cannot argue about it, Kanak. You know my husband has forbidden me to fetch water, and you know him well.' (4-5)

And then the transgression happens suddenly. The sinful act gets performed. Matangini, at the insinuation of Kanakmayee, steps outside her familiar terrain; the interiority, the domestic household which has so far cocooned, shelled, protected, and 'caged' her, in order to fetch water. Precisely the moment when she steps out of the household, the sanctum sanctorum, as it were, she becomes/turns unholy/unchaste/impure in the eyes of the patriarchy; and further weathers the vicious outside storm later (both internally and externally), which can (at least the society thinks to be so) only be taken care of by a male. The patriarchal society has fixed/demarcated her within a certain 'lakshman rekha', the crossing of which would definitely vilify her, stigmatize her, make her susceptible to the lust of the Ravanas of the then Bengali society like Mathur Ghose, thereby making her sceptical to the public eye, and turning her instantly from a 'good woman' to a bad woman. We evidence the first trace boldness (if we may call it so) in the tone of Matangini as she retorts to her husband's chiding for going out to fetch water: 
'Well, queen, where have you been?' The woman firmly whispered back, 'I had gone to fetch water.' She was standing like a statue exactly on the spot where her husband had asked her to stop.

'To fetch water!' taunted Rajmohan. 'But with whose permission did you go out?'

'With nobody's permission.'

'With nobody's permission!' he shouted. 'Have I not forbidden you a thousand times?'

The woman replied in the same even tone, 'You have.'

'Then, wretched girl, why did you go?'

The woman proudly replied, 'I am your wife.' Her face reddened and her voice began to be choked. 'I had gone because I thought there was nothing wrong in it.' (12)

Again, we find this suddenly bold woman, who faces her husband's stiff impositions with so much of resistance, becoming supple to her sister Hemangini, to ask for a suitable job to help her husband out from dire financial straits, instead of leaving him. The tone of affection and care in her voice for her husband is something noteworthy:

'What were you going to ask of me?' enquired Hemangini, wiping her eyes.

'I am poor, Hem, very poor, but were it for me only I would never speak of it to you. But my husband, whatever he is, sister, Heaven made him so - he is my husband and I care for him. He has now nothing to do and is reduced to great straits. He has besought me to ask you to speak to my brother-in-law.'

'Yes, I will; but what shall I ask in his behalf?'

'An employment—-some means of earning a livelihood.' (19) 
So, how are to view/analyse this essential conflict/contradiction in Matangini's character and behaviour? Has her boldness become so good as to renounce her husband Rajmohan completely to indulge in affairs with other males of the society audaciously, indiscriminately? Even later on, after overhearing the conversation at midnight between her husband and the robbers, what she does is just to protect her sister and her brother-in-law even at the cost of her own life. It is primarily her sense of duty which makes her move out of her husband's household at that wee hour. And, it is her bold step which saves both Madhav and Hemangini from a fortune changing and possibly life-threatening attack. Obviously love can conquer fear and it does. But the important question that can/should surface here, is this, which love ultimately conquers fear? For whom is the love ultimately shown? Is it only a duty-bound affectionate love for her sister Hemangini and her brother-in-law Madhav? Or, rather is it something more? Does the real source of Matangini's affection lie somewhere else; that is, for Madhav, her ex-love? The answer perhaps is both. For, Matangini is driven as much by love (for Madhav) as much by her sense of duty, while she goes to Madhav's house. And the text bears ample evidence of her duty-bound nature towards her own kith and kin against the onslaught of her husband Rajmohan and the band of dacoits:

And the victims of this horrible deed were to be her own Hemangini and her Madhav. Her hair stood on end, her blood tingled in her veins, and a sharp pang shot across her head. All thoughts of her own accursed future and degraded womanhood vanished as she thought of the beloved beings who were now sleeping in fancied security while utter poverty and misery, perhaps worse, yawned to engulf them in an hour. She felt she must save them if she could, even at the price of her life. (37-38) 
It is true that Matangini confesses her love brazenly before Madhav after saving him for the danger laid by her husband for him and breaks down emotionally before him, but, this is really a testing question to answer whether this is due to Matangini's still passionate love for Madhav, who is married to her own sister or is it rather because of her own personal miseries, the dearth of love and warmth from her own husband, who offers him nothing but cruelty, mental agony, and unending bullying and humiliation. Also we cannot tell for sure whether it is Matangini's latent/hidden love for Madhav that is the real reason of the disruptive peace in Rajmohan and Matangini's domestic life and whether Matangini has been able to love Rajmohan the way she has loved Madhav. We cannot say whether she is the originator/sutradhar of the entire fiasco of the text herself. We cannot and we should not. But through an extensive analysis of the text, we can discuss how Matangini defines her womanhood in the present text. Bankim, as is evident from the text, places Matangini within a typical patriarchal framework and then lets her experience its different vibes and tunes. As mentioned above, one cannot convincingly say whether all problems of the text actually starts by Matangini's marrying Rajmohan, a person whom she does not love and perhaps cannot love at all, to which Matangini's proclamation gives further boost :

'You are right,' she said. 'I love him—deeply do I love him; long loved I and I love him so. I will also tell you that words have I uttered which but for the uncontrolleduncontrollable madness of a love you cannot understand would never have passed these lips. But beyond this I have not been guilty to you. Do you believe me?' (62)

From a normal view, however, it seems that Matangini gets badly bruised and hurt by the patriarchal dents but on closer inspection, it seems as it were that those bruises and hurts are caused and created by none other than Matangini herself. And her womanhood consists in 
her making choices, taking decisions, supported by needful/sufficient action and speeches. She is someone who is extremely conscious of her own decisions and barring only once, when following her father's choice/wish, she makes the significantly wrong decision of marrying Rajmohan, she normally takes just and reasonable decisions. Starting from fetching water from outside along with her friend Kanakmayee; to forewarning the household of Madhav after midnight (to protect him from dacoits); to returning to the household of her husband even after he tries to murder her and ultimately, to resist/thwart the evil intentions of Mathur Ghosh to possess her body; she almost everywhere takes the right decisions and makes clear assertions of them, backed by a proper and reasonable thinking. She does what she deems right at a particular moment and has a specific logic behind it. And she is not afraid to act accordingly after taking her decision. Her womanhood does not consist of aberrant behaviour or unusual boldness or living a promiscuous life. She does not go here and there and flirt with every other male character or indulges in having affairs almost like a passing fancy or show off her feminine charms to attract the attention of others, so as to earn her the tag of a typically modern woman. If we are to call her modern, it is primarily by her outlook, by her strongly sticking to her principles, and backing them strongly, and not by how she does look or what she wears. Indeed, it is this quality that essentially makes her separate/different/distinct from the other women characters-like Hemangini, Tara who remain submissive and does not get much chance to express themselves (but faced with a similar life-situation like that of Matangini, they could also have changed perhaps). If her proclamation of love for Madhav borders on the aberrant/unusual/taboo, then her resisting the advancement of the villain Mathur Ghose is also just and proper:

'You shall be mine yet, life,' said Mathur, as with a demoniacal look he was departing for that evening. 
'Never!' said Matangini, concentrating the energy of twenty men in her look. 'Never yours. Look here;' and she placed herself immediately in front of him. 'Look; I am a full-grown woman, and at least your equal in brute force. Will you call in allies?' Mathur Ghose stood bewildered at this wonderful challenge. (120-21)

And in the face of all oppositions, she tries to maintain/uphold her essential dignity, integrity, without unnecessarily getting bogged down to anyone or anything. We see her breaking down only once, to Madhav, the person, whom she confesses love for and from whom perhaps, she can expect sympathy/warmth/consolation at time of her utter distress. Incidentally, Madhav, the only suave/polished face of patriarchy, is someone who is removed from the crude/coarse aspects of masculinity; someone who is not brutal like Rajmohan or libertine like Mathur Ghose and is someone instead, whose western education has taught him to be cultured/of having a refined disposition and perhaps, at the same time endowing him with the ability to steer clear of a/any situation which might land him in trouble publicly or defame him. That is why, even after getting the unwanted help from Matangini to save his property and perhaps, life he can't think of being generous to Matangini and try to help her in her time of utter distress; rather timidly shies away from his sense of duty:

'Listen to me, Matangini,' replied Madhav, scarcely cool himself, 'listen and spare both of us this sore affliction. At your father's house the flame was kindled which seems fated to consume us both and which then we were too young to quench by desperate efforts, but if even then we never flinched from the path of duty, shall we not, now that years of affliction have schooled our hearts, eradicate from them the evil which corrodes and blisters them? Oh! Matangini, let us forget each other. Let us separate.' And Madhav heaved a sigh. (56) 
We can well understand that it is not possible for him to respond to Matangini's love, as he is already married to her sister Hemangini. But at least, he could have tried to console/comfort/soothe her at that time when she needed him most as a friend at least and sent her back to her father's house, which he ultimately does at the very end. But then, probably, it becomes too late to let her live again in a dignified manner. Given the education and refinement that he has, we can certainly expect that much of benevolence from his side, at least, as a gratitudinal gesture to what Matangini has earlier done. But unfortunately, we don't see the reflection of his western education on his mindset. It is true that he does not take advantage of Matangini's helpless and hapless situation like Mathur Ghose, but he doesn't try to help her either. In Mathur Ghose, we have the ultimate villain of the novel, who is a scheming, cunning, crooked person, who not only possesses avarice for materialistic possession but also for the mystic female physical beauty and charm. And hence, in spite of having two wives already (obedient Tara and the proud, insolent Champak), he still tries to possess Matangini. So, Mathur represents that essentially exploitative patriarchy, which thinks that a woman is but a commodity to be consumed and enjoyed:

Mathur Ghose was not perhaps formed by nature to love and be loved; affection was not certainly the ruling passion of his heart, but the power of woman and her beauty have their influence upon all, and Mathur Ghose was fond of his wife. Sensibility and refinement of the heart lend to the passion of love the form of a fervent and etherialized feeling which finds its gratification in the communings of heart with heart; while, in grosser natures, it degenerates into the yearnings of desire or perhaps into a blind obedience to the mystic power of female loveliness;...(80-81)

Ultimately, we find that Matangini's life, however, individualistic she is, essentially revolves around the different faces (here four) of patriarchy. And her individuality lies in her 
dealing with them, their different yet somewhat similar mindsets/thinkings (of primarily considering woman as non-important/insignificant); psychologically/mentally, and getting dealt with in return. Her womanhood consists in making/creating room for herself while staying inside/within the patriarchal zone to come out in support of what is right, and just. 


\section{Works Cited}

Chattopadhyay Bnkimchandra. Rajmohan's Wife. India: Penguin Random House, 2009. Print. https://www.wikipedia.org

Walid, M. (2019). Patriarchy, Oppression and Illegal Migration in Leila Lalami's Collection of Short Stories "Hope and Other Dangerous Pursuits". IJOHMN (International Journal Online of Humanities), 5(5), 11. https://doi.org/10.24113/ijohmn.v5i5.140 